\title{
Vida Lahey's Progressive Activism for Children's Art Education
}

\begin{abstract}
This article concentrates on artist Vida Lahey's Queensland-based activism for children's art classes in the context of progressive ideas that circulated between the wars. I argue that Lahey functioned within a wider, wellinformed, democratic elite. Indeed, it was her social and cultural capital, and that of friend and sculptress Daphne Mayo, that enabled Lahey to actively constitute agency. Her activism, produced children's art classes in Brisbane outside of formal educational structures that were slower to respond to progressive ideas.
\end{abstract}

Vida Lahey and Daphne Mayo were well known in their time. Lahey (1882-1968) exhibited nationally and internationally in oils and watercolour, mediums that dominated design interests in woodcarving, linocut, beaten copper and china painting. Although best remembered for her flower paintings, floral titles account only for about forty per cent of her ouvre. Lahey also painted rural, urban and coastal landscapes and scenes featuring predominantly female figures. $\underline{1}$ Her most persistent claim to fame is Monday Morning (1912, QAG). A large oil painting of Lahey's sister and a friend scrubbing clothes at the family washtub, Monday Morning definitively launched Lahey's professional career. She received the Sydney Society of Artists medal (1945), the Coronation Medal (1953) and, in 1958, was appointed a Member of the British Empire (MBE) for services to art. In 1959, the Queensland Art gallery (QAG) commissioned her to write the first history of Queensland art.2 She therefore became increasingly visible as a cultural activist. Her friend and fellow activist, Daphne Mayo (1895-1982) was a well-loved Brisbane sculptor. In Anzac Square, the Queensland Women's War Memorial (1932) depicts Mayo's bas relief frieze of soldiers with a horse drawn gun carriage. Her best known work, however, is the Tympanum above the portico of Brisbane's neo-classical City Hall (1930). When commissioned, this was Australia's second most expensive public art work after the Sydney Harbour Bridge. $\underline{3}$ As activists, Lahey and Mayo pioneered children's art classes in Queensland.

My understanding of the agency in their activism follows feminist theorist Susan Hekman's insistence that, 'agency is defined and circumscribed by the discursive formation; it is not a given condition but a constituted element of subjectivity'. $\underline{4}$ Lahey's position enabled her to implement progressive ideas. The children's art classes were a result of her ability to be a subject accessing what Hekman calls, 'the discursive tools available'. $\underline{5}$ Family support, overseas ideas and experiences, local social networks, committees, and media coverage were all construction 'tools' for her agency. The Gallery became more than a place where the adult public studied the patriarchs or internalised pastoral scenes of colonisation. It also became a space for the education of children as future advocates for peace.

Catherine Speck has analysed women artists who were also teachers. $\underline{6}$ However, my article uses one woman artist and teacher as a case study for understanding agency as the materialisation of personal desires shaped by historical, cultural and institutional contexts. It reveals Lahey's activist leanings from her family background; examines how her writing expressed her activism, her philosophy of art and the personal impact of broader cultural 
concerns; and then examines how Lahey experienced, and then learnt to deploy, institutional structures such as the Queensland Art Fund (QAF) to achieve her aims. The final focus is on the children's art classes as the tangible outcome of Lahey's constitution of agency.

The study of art education between the wars has been dominated by investigations of the imitative model of Britain's South Kensington School of Design and the individual creativity and originality model inspired by Viennese art educator Franz Cizek.7 Much research has examined the influence of these models in Australia. Doug Boughton tracked their arrival from overseas, added the 'studio phase' after 1960, and noted the varied success of Cizek's 'creativity phase'. $\underline{8}$ Jenny Aland scrutinised how South Australian educators were shaped by a consistent institutional preference for South Kensington methods. $\underline{9}$ In the same state, Catherine Speck revealed career tensions for practising women artists who were recruited to teach teachers only to have their professional agency and status as artists destabilised. 10 Gillian Weiss focused on primary education curricula, included Victoria and Queensland in the regional sweep, and traced the shift from technical skills to an aesthetic of art appreciation whilst warning not to mistake rhetoric for practice.11 Tony Rogers demonstrated the British shift well before it reached Australia.12 Sue Malvern examined Cizek's influence in Britain arguing that his 'teaching should be debated as a modernist practice'.13 However, Chris Peers has termed these two pedagogical models 'common perceptions' that dominate the interpretive framework for the study of children's art education and called for 'more detailed scrutiny' of options beyond this imitative-creative binary. Vida Lahey's career offers a way forward as her children's art education exceeded the pedagogical binary of mimicry versus originality in formal educational settings. The traditional value of the 'masters' was retained as a means of appreciating principles of form and colour but children were not expected to slavishly mimic what they were shown ... Little research has been done on Lahey and her work for children's art education in Queensland. There is an excellent history of the Queensland Art Society that mention children's art education only in passing, 14 and Bettina MacAulay's comprehensive Songs of Colour, which was published for Lahey's 1989 retrospective, writes mostly from an art history perspective.15

\section{Background and articulating the cultural context}

Vida Lahey's early family life modelled agency. Her father served on three Shire Councils (Sherwood in Brisbane; Coomera and Tamborine in the Gold Coast hinterland). Indeed, it has been said that the township of Canungra owes, 'its very existence to the Lahey family'. 16 When they needed infrastructure to support their business interests, the Laheys built it, spending £26,000 on tramways and £80,000 on roads with 2,615 feet of bridgework.17 Siblings and cousins were also proactive: in 1960 Romeo Lahey received an MBE for work in the National Parks movement. 18 As a missionary in India for forty-three years, Oswald Lahey built leper hospitals. In California in 1929, cousin May became the first female municipal court judge and Queensland Premier, Sir Frank Nicklin, was a relative. 19

Within this culture of possibility, physical and institutional landscapes responded to human intervention. It also provided enough financial stability to send Lahey to the best girls' school in Southport, Helena Davenport's Goy-te-Lea. 
Despite their success in their artistic fields, and regardless of Lahey's dynamic family ethos, it is doubtful whether either woman alone, or even together, would have been successful had their goal not been in sympathy with a broader cultural shift in pedagogical thinking. During the interwar years in some psychology, art and education circles, 'emancipatory interests' as Celia Jenkins has called such thinking, characterised the modern and underpinned modernism. 20 This found its most complete expression in the New Education Fellowship (NEF). Campaigning against suppression of individuality and obedience to numbing routines, NEF advocates believed children needed a learning environment that developed innate creativity. This would enable independent thinking thereby meeting the goal of fostering, 'world peace and international tolerance'.21 Riding on the institutional infrastructure of the theosophical movement, the NEF quickly became global.22 Simultaneously, greater authority was attributed to psychology that moved beyond Freud's focus on sexuality. Creativity and developmental growth became instrumental in pedagogy. Jung's psychology and French psychotherapist Emile Coués stress on imagination permeate the NEF journal, The New Era. $\underline{23}$

Art became an important instrument for the development of this new emphasis on children's individuality, a principle that found early expression in the 'not to teach' approach of Franz Cizek. For Cizek, a child's art was autonomous and, freed from the restrictions of culture, and wanted only, 'to fulfil its own wishes, inclinations and dreams'. Cizek believed the 'longer a child's subconscious creative powers can be kept in the dark, the better. As soon as they are illuminated by reasoning, they generally cease to exist, because the intellect destroys the child's confidence'.24 Although Cizek had exhibited student work in London in 1908, it was not until 1920 that he became famous. 25 Under the auspices of the Save the Children Fund, an exhibition of students' paintings opened in London. For nearly four years it toured Great Britain (where an estimated two hundred thousand people saw it) the United States, Canada and Australia.26 The organising committee included social reformers, artists and educators and part of its success in changing art pedagogy was that, 'the times were ripe, the teachers' minds were ready, chiefly because of the growing respect for the individuality of the child'.27

Although these ideas were circulating as Lahey and Mayo turned their attention to Queensland art, the will to apply 'progressive' principles also had to exist. A great deal was at stake for the makers and shapers of culture between the wars. At the core of developments in art education, psychology and education generally was a desire to believe that humans were capable of living harmoniously.

Lahey crystallised this progressive will in a lecture entitled 'Art for All' delivered in Brisbane in the early 1940s. Lahey insisted that, 'only by affirming and strengthening the powers that work for peace can fear of war ever be lifted again, and art is one of those powers'.28 She continued:

art is an integral part of life, and what affects life must affect art. Nowadays when every mode of life is in a flux and long accepted values are being questioned and new experiments made in every sphere of thought, is it not inevitable that art should be stirred in the same way? For art is not separate from us, a product of our hands, but it is one of our languages; in fact, it is the only international language-a language which knows no barrier of place or time, and by which spirit speaks to spirit, and century to century.

The universal humanism of art becomes a means of salvation once society better understands it, both for itself and in its social function as the bearer of civilising virtues. Lahey believed 
the 'jarring' or 'discordant' in art were a direct consequence of 'world conditions'.29 Modernist art needed to be accepted as non-natural. Paintings by Cezanne, for example, become 'understandable' only when perceived as working 'symbolically, not as portraits of persons or places, but portraits in which the violence or some other aspect of our times is suggested'. $\underline{30}$ Modernist paintings were the external representation of the artists' psyches.

Lahey's views in 'Art for All' on how modern life separated people from nature and art were influenced by Lewis Mumford, especially his Technics and Civilisation (1938). This was the first of four books in a series called the Renewal of Life by the American, self-styled man of letters and New Yorker's architectural critic for thirty years. Intended to consider 'the city, region, group and personality', its original title, Form and Personality, reflected the pervasiveness of psychology.31 Mumford still had a relatively optimistic view of technology in 1938, but Lahey was less accommodating. Her lecture highlighted the increasingly 'mechanical' 'regimented and uniform' nature of human life and presented the image of 'men as mere cogs in the soulless routine of business'. 32 The machine age repressed nature and humanity. Perhaps what Lahey most shared with Mumford, though, was his 'romantic reaction' to the modern, a commitment to 'organicism' understood as 'a sustained vindication of a single view of reality'. $\underline{33}$ For Lahey this 'single view' was the reintegration of art and life. 'Where lies the blame?' for a failure of integration, she demands. 'It is the fault of the age in which we live, plus the unbalanced education we have all received'. $\underline{34}$

Lahey believed that integrating art into everyone's life, as both fine art and understanding of design oriented principles, is the task of education: '[t]hrough education the orientation of our civilisation could be changed'; and, because '[a]s the twig is bent, so is the bough inclined', educating children was the place to begin. This was 'not to turn every child into an artist, but to develop in each child the capacity to enjoy a new world of delight that is free and could be open to us all if our senses were trained as much as our intellects'.35 As Mumford would soon express it in Values for Survival (1946), 'the supreme task' of Lahey's generation was to self consciously renew values and 'create balanced human beings capable of entering into world-wide co-operation'. $\underline{36}$ For this, discipline and training were still necessary.

What was at stake for social activists like Lahey was their belief in the 'goodness' of human nature, its ability to survive the modern. Through intervention, society could be returned to stability, without sacrificing individuality. Lahey stated adamantly in 'Art for Life':

I would like to make it clear that by increased art education I do not mean merely more of the old fashioned type of drawing lessons that we sparsely received ourselves, but art education along modern lines, which makes enjoyment a spur to effort and aims at drawing out imaginative and constructive ideas rather than merely copying objects in a mechanical manner. $\underline{37}$

Peace, freedom, creativity and agency were high stakes carrying a powerful ideological imprint. For art education, for children in particular and for Queenslanders in particular, the institutional framework necessary to 'carry' and formalise the new agenda was conspicuously absent. In 1933, a representative of the Carnegie Corporation of New York (CCNY) reported that Queensland's Art Gallery obtained, 'less support than in any other city of equal size in the British Empire'. $\underline{38}$

It was fortunate for Lahey's ideas for a children's art project that the CCNY became a major ideological player in Australian cultural politics. In 1928, CCNY's James Russell, identified 
his Corporation's underlying agenda when he warned of the potential perils of state socialism and strong unionism. Australia was one of 'the experiment stations for all English speaking peoples [...] The rest of the world may be worth cultivating but this part needs intensive tillage and irrigation [...] What might happen if the Communists get control can only be imagined by what is going on in Russia'. $\underline{39}$ Russell was not simply referring to the turmoil after the 1917 Revolution but to a general Western fear of a substantive threat from fascism and socialism. 40 The CCNY's support for the arts, adult education and libraries aimed to socially engineer a better, safer future. By 1930, it had donated £50,000 to the establishment and continuity of Australia's first peak body in education, the Australian Council for Educational Research (ACER). 41 Between 1932 and 1935, Carnegie representatives gathered information on Australian adult education, museums, galleries and libraries.

Any change orchestrated by such as CCNY had to be controllable, though, 'led and orchestrated by an elite with the appropriate and approved training, one that supports the existing social structure'.42 Again, this meant training, 'men and women who may interpret the arts to the body of the people'.43 In 1937, ACER and the NEF organised six weeks of conferences in state capitals: '21 speakers gave 300 addresses' with intense press and radio coverage. 44 In art education, by 1941 the CCNY had distributed 302 art education 'sets' to Commonwealth destinations. 45 These included art history books and prints of important paintings, architecture and sculpture.

\section{Deploying institutional structures}

Lahey arrived at Brisbane Technical College, 'some time between 1898 and 1904'. $\underline{46}$ Combined with the optimism her family demonstrated, her experiences there provided a blueprint for her activism. The College, which was closely linked to the Department of Public Instruction, was the only source of training for artists and teachers. It had at least a three-fold impact: first, she met Richard Godfrey Rivers; second, she experienced the South Kensington method, and third, she met Daphne Mayo.

Rivers was a strong personality and something of a College enigma. The College administration and staff were supporters of the South Kensington School of Design, and utilitarianism dominated. Rivers believed the public should have a 'sympathetic attitude to the aims and stand-point of an artist', $\underline{47}$ a view Lahey adopted for her later lecture. Rivers was not content to simply teach or simply paint. Like the Lahey family, if needs existed, he initiated change. Under Rivers' stable leadership, the Royal Queensland Art Society was better able to express demands for an art gallery. $\underline{48}$ When the Municipal Council promised the nucleus of an art collection if a room could be found, Rivers promptly discovered one in Town Hall itself.49 He added £25 to the Council's £50 and paintings from his private collection. $\underline{50}$ When the new Gallery proved inadequate for the needs of the Society, Rivers' private studio became available as a forum. $\underline{51}$

Lahey witnessed this style of personal activism when she was a student and the funding for the Gallery disappeared. $\underline{52}$ In 1909, Rivers facilitated an 'outstandingly successful visiting exhibition of British art' through the Royal British Colonial Society of Artists. 53 Lahey indicated that the expenses were, 'guaranteed by a special committee' led by Rivers. $\underline{54}$ She was well placed to know. By 1910 she and Rivers had formed a Building Fund to raise 
money so the Society could purchase premises independent of the Gallery and its inadequacies. In 1911, this new fund, with Lahey as vice president, ran 'a spectacular coronation pageant'. 55 Through income from this and other events, $£ 500$ was raised in three days. $\underline{56}$ A skilled engineer with the Lahey sawmill earned about $£ 4$ weekly. $\underline{57}$ Prioritising of fine art was implicated in Rivers' 1915 resignation from the College. 58 By then, though, Lahey had already learnt about organisations tailor-made for a purpose.

She also knew about the South Kensington method. Its emphasis was to train teachers, train inspectors to monitor teachers and produce students who were economically competitive in industrial design. Art was design, drawing was a technical skill learnt through the 'free hand', and later the 'free arm', drawing method, a very specific posture for drawing. $\underline{59}$ Creativity and imagination were required only in the final stages for combining the available styles and motifs in a pleasing, profitable manner. There were twenty three:

mechanical steps to the acquisition of "hand power". Twenty-one were successive exercises in copying from the Flat, or Round, or Nature, intended [...] to be strictly imitative until stages 22 and 23 were reached-a most unlikely eventuality. Only a minority of students ever reached stage 10; indeed, sometimes about half the students [...] were only at stage $2 . \underline{60}$

In Australia, this is what Boughton called, 'The Hand-Eye Training Phase' which preceded the 'Creativity Phase' initiated by Cizek's fame.61 It was not, however, displaced by the Creativity Phase even though, by 1895, the South Kensington method was already deregulated in Britain.62 It did not relinquish its hold on the South Australian education system until 1938; $\underline{63}$ and the Queensland struggle to become progressive remained well into the 1940s.64 South Kensington tenets were still valued in art circles in 1953 when Lahey gave vent to her frustration with its tenacity. Regarding a QAG event, she wrote to Mayo:

Mr Davies [...] as head of the Dep't [sic] of Education, and Gibbs as head of Brisbane's only pretence at an Art School, are a good pair! It made you feel as if you'd like to rush out and head up a procession to blow up Parliament House to make them take notice. The theme was "Pictures I like and why" and he started off by a long tirade on the teaching of arts, and announced that he believed in Discipline etc. and then proudly showed a large drawing of an acanthus scroll done from a cast stippled to the last degree. It looked as if it had been done in South Ken. [sic] at least 30 years ago [...] "Well drawn" and "typical of Australia" were the only reasons given for his preferences. $\underline{65}$

During Lahey's time at the Brisbane Technical College, there was an attempt to introduce more progressive American texts.66 The Prang Elementary Art Course, instructed teachers to 'have in mind constantly the development of the imagination'.67 Although '[d]rill exercises should be short, only 'five to ten minutes' it was so full of instructions that a progressive agenda was undermined despite the rhetoric, as Gillian Weiss has revealed.68 The 'General Directions' detailed posture, procedure and method of drawing reminding teachers that, 'Pupils should erase together as a class'. $\underline{69}$ The first graphic illustrated the correct way to hold a pencil.

James Liberty Tadd's New Methods in Education, had similar drill exercises.70 The first graphic, preceding even the title page, however, was a photograph of students drawing a butterfly from life. Tadd provided a "wealth of illustrations', many of them photographs. His 'First Principles' covered sixty-four pages continuously emphasising enjoyment, engaging 
with life rather than copies and experimentation to understand how old masters achieved their effects.

Lahey found in Rivers a role model who echoed the vigorous dynamic of her family. Her formal art education exposed her to the South Kensington method and possibly some alternatives. By 1913 her reputation was assured. She had been on a New Zealand painting tour (1902); exhibited interstate; belonged to the Victorian Art Society (1905); exhibited annually with the Queensland Art Society since 1907; and was a committee member (1908), a member of its exhibition committee and fund raising committee (1910) and its vice president in 1913. Lahey had attended the National Gallery School in Melbourne (1905, 1906, 1909), was a multiple prize winner, and Monday Morning was in the Queensland Gallery (1912).71 She had her own studio in George Street which, like Rivers, she made available as a forum.72 From 1916-1921 she went overseas to support her family in the Great War.73 Afterwards, she went to view the European masters, study in Paris with Ethel Carrick Fox and at Colarossi's studio (1919); and went to St Ives in Cornwall to study with New Zealander Frances Hodgkins (1920). 74

When Daphne Mayo came to the Brisbane Technical College in 1911, Lahey was a leader in the local art scene, artistically and administratively. Mayo (1895-1982) had never left Brisbane and had no contacts. This would change when the high profile, national, patriotic organisation, the Wattle Day League, encouraged by Rivers, created a travelling scholarship to London's Royal Academy of Art-Mayo was the first recipient. $\underline{75}$ Although the war delayed travel until 1919, in 1925 she returned to, 'unprecedented and amazing public patronage' soon receiving commissions from Brisbane's elite such as Sir Matthew Nathan, the State Governor. $\underline{76}$

By 1927, then, due to their studies and travel, both women believed that Queenslanders and Queensland artists needed exposure to interstate and international art. Just as Lahey and Rivers had spearheaded the Building Fund, Lahey and Mayo formed the Queensland Art Fund (QAF), modelled on Britain's National Art Collection Fund, specifically to buy overseas artwork for QAG.77 The combined networks of the two women provided ideal targets for fund-raising activities. Plans were only delayed by Lahey's second departure for Europe in 1927. Whilst there, however, she saw an exhibition by Cizek's students and the philosophy for the children's art classes began to take firmer shape. $\underline{78}$

\section{The Queensland Art Fund}

Lahey now had an organisational model, a mode of activism and, with Mayo, social networks to support the QAF campaign to develop art appreciation through 'Art for All'-and improving the QAG collection. Classes, as such, were not yet on the agenda. QAF's concerns were membership, publicity and funds. At the inaugural meeting, Archbishop Duhig and Archbishop Sharp were joint vice presidents whilst Lahey and Mayo were on an Art Advisory Committee.79 It would soon (adamantly) 'advise' the Gallery on expenditure of thousands of pounds of QAF donations, thereby creating some QAF leverage within the Gallery administration. Mayo's network also included the widow of Richard Godfrey Rivers. 80 Selina Rivers wanted to support QAG through a lucrative annual bequest in her husband's name administered by the QAF. 
Lahey and Mayo encouraged two preconditions that further increased QAF influence in Gallery matters. The first was the replacement of the Gallery's Curator and Board of Advice, with Trustees and an Art Advisory Board, drawn from various art organisations (including the QAF). On the Board of Advice since 1923, Lahey had actively campaigned for a more 'responsible body'.81 The second precondition was relocation of the Gallery. Since 1905, it had been in a long, dark room on the third floor of the Executive Building in George Street. This was despite agitation by the Architectural and Building Journal of Queensland, the National Council of Women and the University of Queensland. They had long sought a Gallery with adequate space, lighting and public accessibility, one that would also train 'fine' artists. 82 This led to the refurbishment of the Exhibition Concert Hall at Gregory Terrace (1929-1931).83 A decade later, this building would house the children's art classes.

The Godfrey Rivers Bequest, the 1930 Southern Loan Exhibition which showed interstate work and rare prints of international modernists, and the Darnell Appeal that raised £15,000, enabled the QAF to achieve its primary goal of improving public appreciation of a greater range of art.84 However, the QAF aspired to more than new Gallery space and fiscal strength. It also espoused the philosophy Lahey expressed in Art for All: everyone can benefit from proper art awareness, 'we wanted Art education in the State Schools to be taught by teachers with Art Training' declared Mayo. $\underline{85}$

How was a new regime for Art education in schools to be realised? The QAF minutes, taken in the 'Lord Mayor's private sitting room,' reveal considerable discussion of this goal. One suggestion was 'organising the schools and inviting the children to subscribe to buy a picture, which might be a gift from them to the Art Gallery'; Archbishop Duhig believed 'that the secondary schools should be approached first— \& that by arranging visits to the Gallery, \& winning interest in various ways, the schools might become associated with the Gallery and work for it'. The Lord Mayor Mr Jolly suggested giving lectures at the Gallery, and then awarding a prize for the best essay on the subject. $\underline{86}$

When Mayo, Archbishop Duhig, William Bustard from the Royal Art Society, and Chief Justice, Mr Herring visited the education Minister's office in December 1931 seeking departmental support, 'in spreading knowledge of Art through the schools', they were greeted by only the Minister's spokesman.87 The Minister's representative, 'expressed sympathy', but insisted that the Department, 'discouraged collections through the schools'. He promised to brief the Minister and advise the outcome. $\underline{88}$

Four months later, nothing had been heard. A letter and an attempt to 'find the proper mode of approach' ensued.89 At first, the Department resisted attempts at interference by fine artists and their recruited elite. Finally, it provided a list of metropolitan schools for the QAF to approach, but disallowed financial collections or support for lectures. Not yet having a dedicated space for students, the QAF decided, 'that the matter of approaching the schools should stand over for the time being'.90 The Depression soon became cause for further 'abeyance'.91 Departmental prioritising of the skill and design focus in art education was preserved.

The QAF clearly needed a different structure than state schools to support its educational goals. In 1933, Mayo approached the CCNY with some success when its representatives were in Brisbane.92 In its 1934 report, CCNY recorded: 'We would urge this little body not to wait but to go ahead and blaze a new trail in Australia'.93 In 1935, it presented to the Art Fund a set of Art Teaching equipment. This consisted of '200 books, \$2000 photographic 
reproductions, a set of 20 original prints, etchings \& lithographs \& engravings, \& a group of large colour facsimile reproductions intended for exhibition purposes'.94 CCNY's patronage of a self-helping 'democratic elite' with worthy leaders produced the Queensland Art (Fund) Library in Police Court Lane, off George Street.

The QAF Library was never just a Library. With Lahey as its custodian, its first exhibition included a 'display from the collection in the possession of Brisbane Boys College'.95 It became an educational hub, complete with lecture room and exhibition space. In two years, Lahey organised fifty-five lectures.96 Her interest in children increased. In 1938, she gave radio talks on children's art, and organised a Ships and the Sea in Art exhibition to be 'open during the school holidays'. $\underline{97}$

The final stage of 'Art for All' was not to simply view art but to do art. The conceptualising of the art classes came when Mayo, returning from Europe to Australia via New York, acquired a travel grant and introductions from the CCNY to art class organisers in the galleries of Montreal, Ottawa and Toronto. $\underline{98}$ Toronto particularly impressed her. She saw, '500 children waiting for admission' and in the Gallery space, she saw them sitting on the floor: 'using poster paints direct and not drawing their ideas first'. $\underline{99}$

Arthur Lismer, supervisor of the Toronto Gallery, had attended the Aust ralian New Education conferences of 1937. His 'infectious enthusiasm' for new teaching methods was supported by an exhibition from Toronto, said to bear 'eloquent witness to what the child is capable of when given the right encouragement'.100 His method was to draw minimally, have a 'friendly talk' expanding ideas, encourage drawings on any aspect of the group discussion, observe reality and then compare it to the representations, so children, 'saw for themselves where mistakes lay, and said so'.101 His Saturday morning classes reportedly attracted 6,500 children over six years, whilst annually, 27,000 attended weekly classes. 102 Mayo reported back to the QAF, urging 'representations to the trustees of the Art Gall[ery]' for a similar model, in the Art Gallery. 103 Philosophy, format and location were determined.

Whilst waiting for a response, Lahey joined Mayo in Sydney, sharing her studio whilst she learnt about art education from Margaret Rees (Lloyd Rees' wife) at the Moore Park Children's Library.104 She also made links with Sydney artist, Rah Fizelle. In 1932, the Crowley-Fizelle school had been an early modernist influence.105 The modernist aesthetic, like New Education and psychology, was underpinned by a focus on the individual. Women like Crowley, Preston, Proctor, Cossington-Smith and Dorrit Black were leading the way. $\underline{106}$ Artist Frank Hinder recollected that within the Crowley-Fizelle School, Fizelle taught the, 'then revolutionary creative approach of expressionism [...] as opposed to the "draw the banana" method'.107 The modernist focus on 'inventive, primitive and expressive modes produced a reconsideration of the values of children's art'.108 During the NEF conference, Sydney art critic, Barbara Goode Matthews, pointed out that, 'as far back as 1925', Fizelle had 'experimented' with progressive teaching at Darlington Public School.109 He repeated the 'experiment' at Balgowlah Public School, exhibiting student work at Grosvenor Galleries, 'an unprecedented context for children's art'.110 Lahey knew, or knew of, Fizelle well enough to write to Mayo:

please ask Mr Fizelle this-If the children are allowed to do what they are most interested in, the boys would do nothing but aeroplanes. Should I let them give rein to this desire? Should I check them if they want to talk \& sing as they work? $\underline{111}$ 
Sadly, no answer survives, though it can be imagined. In Brisbane in September and October 1940, the QAF Library exhibited children's art from Toronto, Sydney and Brisbane. Margaret McNeil, who had already been teaching art to children in Tasmania, gave a lecture on the topic. 112

In December 1940, the Gallery responded to Lahey and Mayo's proposal, which had come via the auspices of the Combined Art Committee representing multiple local art organisations. Lahey was appointed 'to take charge of the course of training, and to proceed along the lines suggested by her'. The Trustees 'expected' a monthly report'. $\underline{113}$

\section{Art classes}

In March 1941, Lahey commenced teaching a two-hour class each Saturday morning in the old Portrait Gallery.114 This was 'detached from the main Hall [...] the floor accommodating the needs of the children sufficiently well'.115 The arrangement protected the contemplative public space of the main Gallery from the potential disruption caused by the extraordinary presence of children. A subcommittee looked to 'the more efficient working and comfort of the class', and 'to deal with Miss Lahey's requirements'.116 Mayo described the room's transformation:

the children have a small room of their own, where they sit on the floor to paint their pictures. What was once a melancholy and dark room, called the Portrait Gallery, underwent a metamorphosis when the portraits were banished and a coat of ivory kalsomine put on the walls. Curtains and a little furniture of light golden colour was added, and soon one wall was hung with gay colourful drawings by the children.117

Lahey hoped that, 'the room itself should serve to emphasize the fact that Art is concerned with everyday things, as well as old paintings and statues' and she therefore added 'pictures, books, curtains, art objects and flowers [...to create] an effect of cheerfulness'.118 Before the April QAG meeting, she conducted the first class. In Art for Children (1946), she recalled:

Modern practice aims above all to stimulate the child's creative powers, and by the continued use of these powers to gradually develop their grasp of realism and technical skill, never pointing out such things as proportion and perspective, but always allowing the children to realise these difficulties at their own pace and at their own time [...] it is wrong to regard the progress of the child's Art towards realism as necessarily an improvement [...] A child of 13 years is not better than he was at 7-he is different. 119

The art classes were a combination of teaching of skills and various progressive ideas. The Toronto Gallery provided, 'paints, brushes, ink and crayons', so did QAG; the Toronto children worked on the floor, directly in paint without drawing, so did Lahey's students. 120 The QAG 'Scholarships' were more formal, though, than Lismer's '500 children' waiting to enter the Gallery. They lasted a year and were potentially renewable. Lahey's classes were much smaller than Lismer's. Students were 'picked', like those of Cizek.121 Again, like Cizek, Lahey opted to teach eight- to twelve-year olds describing this developmental age as the 'pseudo-realist stage' when 'the child begins to be more aware of the "real" appearance of things, and [...] a false standard of excellence can supervene [...if] feeling for pattern and 
rhythm, and [...] sense of colour' is lost.122 The first students were selected from Kelvin Grove, Junction Park and Buranda primary schools via an invitation to, 'apply for placement by submitting a visual response to a particular theme'.123 Like Lismer's in-class method, responses were broad, but developed from a supplied idea. Cizek, Lismer and Lahey all exhibited the children's work inside and outside the classroom. 124

Past student, Gary Winters, who still hangs a print of Monday Morning on his wall, is now a professional artist specialising in marine art. He recalled of the classes that students:

could move freely and although I suppose we could talk together the accepted discipline of the day prevailed and I didn't converse with any other student. Things at that time were quite different! The classes were relaxed but I realised the privilege of attending something exclusive-I've never forgotten the feeling of being a 'selected' one! $\underline{125}$

Brisbane-based Terry Wilkinson remembers the classes being 'great fun' and that Lahey would 'take us down through the art gallery and get us all talking'.126 Winters, recalls this too, though he worked silently:

we looked at and discussed items such as urns, stained glass, tapestries, sculpture and paintings to consider shape, proportion and colour. ... I gained a new way of looking at places, objects and people which remains with me and constantly strengthens. ... My paintings of people/ships 'working' or 'doing something' reflect my early experiences with Ms Lahey. $\underline{127}$

Increasing awareness of shape, proportion and colour was clearly a part of actively teaching rather than giving completely free rein to creativity. Wilkinson also felt she had 'been given that gift, that honour of being someone'. The 'honour' changed her from a shy child to a confident one. At art classes she:

just fitted. At primary school I felt I never quite fitted. School work improved because I was encouraged. I never felt like an idiot. I started to concentrate and focus [... .] just painting and painting, mixing colour. I love colours, and not much shyacking going on, we were just too busy. We never got into trouble but [were] always encouraged, encouraged.

Being chosen for the classes motivated Wilkinson enough, at nine-years old, to travel four hours by tram to and from the Gallery. Dale Marsh, another contemporary artist, also gives a clear indication that Lahey's teaching was partly skills based:

With enthusiasm she would describe to us the beauty of a pattern created by the relationship of positive and negative shapes working together, and go on to point out the wonder of subtlety in a coloured surface. As she spoke, we would begin to see those things for the first time, then afterwards, you saw them everywhere. In the rooms of that old art gallery, we became consciously aware of important things like the joy of colour harmony, and the beauty and quality of a drawn line. She was an advanced painter for her time. $\underline{128}$

The environment Lahey created was transformative. The classes encouraged students as Judith Rodriguez said to be 'big and bold [...] to fill the paper'.129 Although the Gallery itself was still criticised by a journalist, Clive Turnbull, as 'ugly', 'wholly unsuitable' with walls that created 'an atmosphere of despair', the children's classes were 'enterprising' and their paintings showed a, 'fundamental sense of values'.130 
The QAG Scholarships remained long after Lahey stopped teaching. They survived the evacuation during the 1974 floods, transferring to the MIM Building in Ann Street until going to South Bank (1982). Free Saturday morning classes continued; selection remained through portfolio response to a theme; recruitment continued via local schools. After two generations a shift occurred in 2003, though the name 'Trustees' Creative Art Scholarships' was retained. Four weekend workshops replaced Saturday morning classes. Tutors were assigned and workshops focused on Gallery exhibitions, seeking personal interpretations from the children.131 In 2006, the Art Gallery opened a Children's Art Centre complete with an education unit. Regular provision of as much as possible for larger groups became the priority; the first Festival for Children attracted 50,000 visitors in only two weeks.

\section{Conclusion}

The Lahey family's social and economic security created an ethos and an education that positively shaped Vida Lahey's sensibility as an activist. In Rivers, she found a role model for her activism. From her years at the Technical College, she carried forward three principles that were central to the establishment of the children's art classes in 1941: A belief that art should be creative rather than mechanical; the recognition that, institutionally, agency and activism involved tailor-made organisations; and an extended personal network.

The belief that art should be creative was reinforced by witnessing Cizek's art classes in the 1928 exhibition in Europe and Mayo's Canadian discoveries gave a format to that belief. The institutional dimension translates, in poststructuralist terms, to the recognition that ideas and desires have to be worked upon and embodied if they are to be (re)produced. The cultural shifts between the wars created a generation whose 'supreme task' was to self-consciously renew social values but this required specific organisations. The children's art classes would not have existed without the influence of Cizek and the supporters who disseminated his ideas; without influential participants in the New Education Fellowship, like Lismer, who drew on new educational psychologies of child development and made a space to apply them; or without organisations like the Carnegie Corporation that consciously intervened in cultural politics. However, not everyone had the networks of social and cultural capital to respond to such stimuli. Lahey and Mayo developed that capital and shared complementary differences. Mayo was dynamic, able to draw publicity to a cause. Lahey was steadier and deeply embedded in a Queensland context that she loved.

The presence of children engaged in the process of creating art in a gallery provided an alternative to the formal education system. The classes were not conducted under the auspices of any single art society; nor were they lessons of the type many artists conducted privately; nor did they draw exclusively on one overseas pedagogical model. Lahey and Mayo pioneered a different gallery experience for new patrons because they believed in the transformative potential of art.

\section{Notes}

${ }^{1}$ MacAulay, 32-7. 
${ }^{2}$ Shirley Lahey, The Laheys: Pioneer Settlers and Sawmillers (Brisbane: Self Published, 2003), 479.

${ }^{3}$ Jeff Waters, 'City Sculptures', Transcript ABC Stateline Radio Broadcast, 19 November 2004.

${ }^{4}$ Susan Hekman, Moral Voices, Moral Selves (Cambridge, UK: Polity Press, 1995), 110.

${ }^{5}$ Susan Hekman, Moral Voices, Moral Selves (Cambridge, UK: Polity Press, 1995), 90. Hekman suggests agency is 'produced by agents who utilise the discursive tools available to them'. I prefer 'subjects' since Lahey and Mayo were not successful 'agents' until those tools were accessed.

${ }^{6}$ Catherine Speck, 'Women Teachers at the South Australian School of Art, 1888-1968', Australian Art Education 20, no. 3 (1997): 33-46.

${ }^{7}$ Chris Peers, 'Mapping Histories of Art Education in New South Wales', Historical Studies in Education/Revue d'histoire de l'éducation 15, no. 2 (2003): 299.

${ }^{8}$ Doug Boughton, 'The Changing Face of Australian Art Education', Studies in Art Education 30, no. 4 (Summer, 1989): 197-211.

${ }^{9}$ Jenny Aland, 'The Influence of the South Kensington School on the Teaching of Drawing in South Australian Schools', Australian Art Education 15, no. 1 (May 1991): 45-53.

${ }^{10}$ Speck.

${ }^{11}$ Gillian Weiss, 'From Skills to Expression: the Arts in the Early Years of School, 18801970', Australian Art Education 16, no. 2 (Autumn 1992): 32-8.

${ }^{12}$ Tony Rogers, 'From the Technical to the Aesthetic in British Art Education', Australian Art Education 15, no. 1 (May 1991): 17-23.

${ }^{13}$ Sue Malvern, 'Inventing “Child Art”: Franz Cizek and Modernism', British Journal of Aesthetics 33, no. 3 (July 1993): 263.

${ }^{14}$ Keith Bradbury and Glenn Cooke, Thorns and Petals: 100 Years of the Royal Queensland Art Society (Brisbane: RQAS, 1988).

${ }^{15}$ Bettina MacAulay Songs of Colour: the Art of Vida Lahey (Brisbane: QAG, 1989).

${ }^{16}$ M. Curtis, Canungra Heritage 1879-1979 (Brisbane: Self Published, 1979), 17, 23.

${ }^{17}$ Robert K. Morgan (rev. Frank Stamford) Lahey's Canungra Tramway, (Melbourne: Light Railway Research Society of Australia Inc, 2000), 11, 19.

${ }^{18}$ Shirley Lahey, 255-6, 385-7, 480.

${ }^{19}$ Shirley Lahey, 346, 204, $103 f f$. 
${ }^{20}$ Celia Jenkins, 'New Education and its Emancipatory Interests (1920-1950)', History of Education 29, no. 2, (2000): 147.

${ }^{21}$ Jenkins, 147.

${ }^{22}$ Kevin Brehony, 'A New Education for a New Era', Paedagogica Historica 40, no. 5 (2004): 735-7.

${ }^{23}$ Jenkins, 141; Brehony.

${ }^{24}$ Cizek in Malvern, 267.

${ }^{25}$ Si ân Roberts, 'Exhibiting Children at Risk: Child Art, International Exhibitions and Save the Children Fund in Vienna, 1919-1923', Paedagogica Historica 45, no. 1 (2009): 183.

${ }^{26}$ Si ân Roberts, 'Exhibiting Children at Risk: Child Art, International Exhibitions and Save the Children Fund in Vienna, 1919-1923', Paedagogica Historica 45, no. 1 (2009):, 177.

${ }^{27}$ Marion Richardson in Roberts, 183.

${ }^{28}$ Vida Lahey, Art For All (Brisbane: Queensland National Art Gallery for the Combined Art Committee of Queensland, 194* [sic]), 1.

${ }^{29}$ Vida Lahey, Art For All (Brisbane: Queensland National Art Gallery for the Combined Art Committee of Queensland, 194* [sic]), 2.

${ }^{30}$ Vida Lahey, Art For All (Brisbane: Queensland National Art Gallery for the Combined Art Committee of Queensland, 194* [sic]),, 3-4.

${ }^{31}$ Rosalind Williams, 'Lewis Mumford as a Historian of Technology in Technics and Civilization', in Thomas P. Hughes and Agatha C. Hughes (eds) Lewis Mumford: Public Intellectual (New York: Oxford University Press, 1990), 43.

${ }^{32}$ Lahey, Art for All, 3.

${ }^{33}$ Leo Marx, 'Prophet of Organicism', Working Paper No. 2, (MIT, Boston: Program in Science, Technology and Society, ND): 5-6.

${ }^{34}$ Lahey, Art for All, 4.

${ }^{35}$ Lahey, Art for All, 5.

${ }^{36}$ Mumford at Eugene Halton, 'A Brief Biography of Lewis Mumford (1895-1990)', Accessed 8 February 2010 from the website: http://www.nd.edu/ ehalton/mumfordbio.html

${ }^{37}$ Lahey, Art for All, 6.

${ }^{38}$ S. F. Markham in Judith McKay, Daphne Mayo, Sculptor (Masters Thesis, University of Sydney, 1981), 142. 
${ }^{39}$ Michael White, 'Carnegie Philanthropy in Australia in the Nineteen Thirties', History of Education Review 26, no. 1, (1997): 5.

${ }^{40}$ Nadezhda Krupskaya epitomised this threat. Krupskaya's principles, in more than 3000 publications including Education and Democracy (1917) were couched in emancipatory, anti-elitist, socialist rhetoric. See Mihail Skatkin and Georgij Cov'janov, 'Nadezhda Krupskaya, 1869-1939', Prospects: the Quarterly Review of Comparative Education 24, no. 1/2 (1994): 49-60.

${ }^{41}$ White, 7.

${ }^{42}$ Edward Berman, The Ideology of Philanthropy (Albany: University of New York Press, 1983), 33.

${ }^{43}$ Ellen Condliffe Lagemann, The Politics of Knowledge: the Carnegie Corporation, Philanthropy and Public Policy (Chicago: University of Chicago Press, 1989), 103.

${ }^{44}$ White, 154.

${ }^{45}$ Lagemann, 111.

${ }^{46}$ MacAulay, 15

${ }^{47}$ Bradbury and Cooke, 31.

${ }^{48}$ Bradbury and Cooke, 19.

${ }^{49}$ Vida Lahey Art in Queensland, 1859-1959 (Brisbane: Queensland National Art Gallery), 10 .

${ }^{50}$ Bradbury and Cooke, 60, 25. Although Oscar Fristrom and Isaac Walter Jenner were also instrumental this is irrelevant to Lahey's development so not detailed.

${ }^{51}$ Bradbury and Cooke, 60, 25. Although Oscar Fristrom and Isaac Walter Jenner were also instrumental this is irrelevant to Lahey's development so not detailed, 138.

${ }^{52}$ Lahey, Art in Queensland, 10.

${ }^{53}$ Janet Hogan, 'Rivers, Richard Godfrey' Australian Dictionary of Biography (Melbourne: Melbourne University Press, 1988), 397.

${ }^{54}$ Lahey Art in Queensland, 11.

${ }^{55}$ Hogan, 397.

${ }^{56}$ Bradbury and Cooke, 138-9.

${ }^{57}$ Shirley Lahey, 234.

${ }^{58}$ Lahey Art in Queensland, 10; Braben, 33. 
${ }^{59}$ Arthur Efland, A History of Art Education (Columbia: Teacher's College Press, 1990), 5760.

${ }^{60}$ S. MacDonald in Aland, 46.

${ }^{61}$ Boughton, 198-9.

${ }^{62}$ Efland, 139-40; Rogers, 21.

${ }^{63}$ Aland, 52.

${ }^{64}$ Braben, 40-5.

${ }^{65}$ Letter to Daphne Mayo from Vida Lahey, 8 Nov. 1953. Mayo Papers, Box 58: Incoming 1950s, Fryer Library, Queensland University.

${ }^{66}$ Braben, 31.

${ }^{67}$ John S. Clark, Mary Dana Hicks and Walter S. Perry, Teachers Manual for the Prang Elementary Course in Art Instruction (Boston: Prang Educational Company 1890), xi.

${ }^{68}$ John S. Clark, Mary Dana Hicks and Walter S. Perry, Teachers Manual for the Prang Elementary Course in Art Instruction (Boston: Prang Educational Company 1890), 4.

${ }^{69}$ John S. Clark, Mary Dana Hicks and Walter S. Perry, Teachers Manual for the Prang Elementary Course in Art Instruction (Boston: Prang Educational Company 1890), xiii.

${ }^{70}$ J. Liberty Tadd, New Methods in Education (New York: Orange Judd Company, 1899), 68.

${ }^{71}$ MacAulay, 8-9.

${ }^{72}$ Lloyd Rees, Peaks and Valleys (Sydney: Angus and Robertson, 1988 ed), 98.

${ }^{73}$ See Sue Lovell, '“Dew to the Soul”: One Australian Artist's Response to the War', Journal of Australian Studies 88, (2006): 13-26.

${ }^{74}$ MacAulay, 9; Bradley and Cooke, 77.

${ }^{75}$ McKay, 33.

${ }^{76}$ McKay., 32, 43, 89.

${ }^{77}$ Bradbury and Cooke, 64

${ }^{78}$ MacAulay, 10, 29.

${ }^{79}$ MacAulay, 10; McKay, 147.

${ }^{80}$ Bettina MacAulay 'Richard Godfrey Rivers, Private and Public Art', Art Off Centre, ed. Glenn R. Cooke (Brisbane: Queensland Studies Centre, Griffith University, 1997), 88. 
${ }^{81}$ MacAulay Songs, 27; Bradbury and Cooke, 65.

${ }^{82}$ Bradbury and Cooke, 62-63.

${ }^{83}$ QAG 'History' from the website: http://www.qag.gov.au//about-us/history

${ }^{84}$ McKay, 143; MacAulay, Songs, 23.

${ }^{85}$ In McKay, 145.

${ }^{86}$ QAF Meeting, 1 July 1931, QAF Papers, Box 1, Fryer Library, Queensland University.

${ }^{87}$ Report on Deputation to Minister for Education' QAF Meeting, 11 April 1932, Ibid.

${ }^{88}$ 'Report on Deputation to Minister for Education' QAF Meeting, 11 April 1932.

${ }^{89}{ }^{\prime}$ Report on Deputation to Minister for Education' QAF Meeting, 11 April 1932.

${ }^{90}{ }^{\prime}$ Report on Deputation to Minister for Education' QAF Meeting, 11 April 1932., Meeting 20 July 1932.

${ }^{91}$ 'Report on Deputation to Minister for Education' QAF Meeting, 11 April 1932., Meeting 1 August 1932.

${ }^{92}$ McKay, 166-7.

${ }^{93}$ Courier Mail, Saturday 17 February 1934, 9.

${ }^{94}$ CCNY Letter, Minutes QAF Executive Meeting, 13 March 1935.

${ }^{95}$ CCNY Letter, Minutes QAF Executive, Meeting 20 November 1936.

${ }^{96}$ MacAulay, Songs, 24.

${ }^{97}$ The Queenslander, 17 August 1938, 44.

${ }^{98}$ White, 10; McKay, 170.

${ }^{99}$ 'Art Training for Very Young Children: Daphne Mayo Abroad', Sydney Morning Herald, 27 December 1939, 3.

${ }^{100}{ }^{\prime}$ Art and the Child', Sydney Morning Herald, 4 September 1937, 16.

${ }^{101}$ 'Developing Art in the Child', Sydney Morning Herald, 21 December 1937, 4.

${ }^{102}$ 'New Education Fellowship: Addresses in Canberra Schools' Sydney Morning Herald, 21 August 1937, 4.

${ }^{103}$ QAF Executive, Minutes 16 February 1940. 
${ }^{104}$ McKay, 170.

${ }^{105}$ Jeanette Hoorn, (Ed) Strange Women: Essays in Art and Gender (Melbourne: Melbourne University Press, 1994), 44.

${ }^{106}$ Jeanette Hoorn, (Ed) Strange Women: Essays in Art and Gender (Melbourne: Melbourne University Press, 1994), 44; Helen Topliss, Modernisn and Feminism: Australian Women Artists 1900-1940 (Roseville: Craftsman House, 1996).

${ }^{107}$ In Eileen Chanin, Steven Miller and Judith Pugh, Degenerates and Perverts (Melbourne: The Miegunyah Press, 2005), 103.

${ }^{108}$ Rosemary Richards, 'Outdated Relics on Hallowed Ground: Unearthing Attitudes and Beliefs About Young Children's Art', Australian Journal of Early Childhood 32, no. 4 (December, 1997): 24.

${ }^{109}$ Letter to the Editor Sydney Morning Herald, 18 August 1937, 6.

${ }^{110}$ Daniel Thomas, 'Fizelle, Reginald Cecil Grahame (Rah)', Australian Dictionary of Biography, (Melbourne: Melbourne University Press, 1981), 519.

${ }^{111}$ Letter to Daphne Mayo from Vida Lahey, Mayo Papers, Box 58, Incoming 1950s, Folder: Undated. Vida had finished teaching by this time so this letter is probably filed incorrectly.

${ }^{112}$ MacAulay, Songs, 31.

${ }^{113}$ Meeting 19 December 1940, QNAG Minute Book 1938-1943, QAG Archives.

${ }^{114}$ Meeting 19 December 1940, QNAG Minute Book 1938-1943, QAG Archives, 3 March 1941.

${ }^{115}$ Meeting 19 December 1940, QNAG Minute Book 1938-1943, QAG Archives, 3 March 1941, Lahey 'Report to Trustees' 1941.

${ }^{116}$ Meeting 19 December 1940, QNAG Minute Book 1938-1943, QAG Archives, 3 March 1941, Lahey 'Report to Trustees' 1941.

${ }^{117}$ McKay, 172.

${ }^{118}$ Lahey, 'Report'.

${ }^{119}$ Vida Lahey, Art for Children (Brisbane: Queensland National Art Gallery, c1946), 4. Emphasis in the original. Copy in Charles Lancaster Papers, Fryer Library University of Queensland, UQFL2.

${ }^{120}{ }^{\prime}$ Addresses in Canberra Schools', 4; MacAulay, Songs, 31.

${ }^{121}$ Malvern, 269.

${ }^{122}$ Lahey Art for Children, 3. 
${ }^{123}$ Melina Mallos, Curriculum and Education Programs Officer, QAG. Personal correspondence, Brisbane.

${ }^{124}$ 'Youngsters Learn But They Also Play', Telegraph, 25 August 1941.

${ }^{125}$ Gary Winters, correspondence with author, 30 April 2006.

${ }^{126}$ Interview with Terry Wilkinson, 2 May 2006, Victoria Point, Brisbane. Notes with author.

${ }^{127}$ Winters correspondence.

${ }^{128}$ In Shirley Lahey, 469.

${ }^{129}$ Judith Rodriguez in MacAulay, Songs, 31.

${ }^{130}$ Clive Turnbull, Letter to Sunday Mail, 21 November 1943.

${ }^{131}$ Melina Mallos. 